\title{
EDITORIAL
}

\section{Educational Equity: The Call of Global Education}

\author{
Marta Pellegrini, ${ }^{1}$ Silvia Dell'Anna ${ }^{2}$ \\ 1. Department of Education, Languages, Intercultures, Literatures and Psychology, University of Flor- \\ ence, 50121 Florence (FI), Italy \\ 2. Faculty of Education, Free University of Bozen-Bolzano, 39042 Brixen (BZ), Italy
}

\begin{abstract}
"The problem with our education system is not that parents do not have a choice.
The problem is that inequities continue to exist."
\end{abstract}

--Patsy Mink

\begin{abstract}
S an indivisible sub-system of society, education is relatively independent and deeply restricted by the social environment. The issue of education equity is regarded as an extension and expansion of social equity in education. It is a vital link that cannot be ignored in education and an essential cornerstone of social justice.

In 1994, UNESCO held the "World Conference on Special Needs Education: Access and Quality" (World Conference on Special Needs Education: Access and Quality) in Salamanca, Spain. At the conference, the educational concept of Inclusive Education was put forward emphasizing that education should be an educational process without exclusion, discrimination, and classification. With the deepening of relevant research, the connotation of inclusive education is constantly enriched and deepened, and the focus of attention has also expanded from more specific persons with disability to those marginalized by political, economic, and cultural factors, and even ignored and excluded by traditional education group (International Bureau of Education, UNESCO, 2009).
\end{abstract}

(C) 2021 Insights Publisher. All rights reserved.

(c) (i) (2) Creative Commons Non Commercial CC BY-NC: This article is distributed under the terms of the Creative Commons Attribution-NonCommercial 4.0 License

(http://www.creativecommons.org/licenses/by-nc/4.0/) which permits non-commercial use, reproduction and distribution of the work without further permission provided the original work is attributed by the Insights Publisher. 
One of the basic concepts of inclusive education is: the right to education is a fundamental human right and the foundation for building a fairer society. This basic educational philosophy emphasizes that everyone has the right to education. Regular schools should admit all children to school and provide them with the education they need appropriately.

However, in this process, the unfair phenomenon of being deprived of the right to education due to factors such as gender, economy, and culture has gradually appeared. For example, the dropout of girls and young women from school (World Bank, 2018), the difference in educational opportunities and educational resources between children in poor and developed areas (United Nations Department of Economic and Social Affairs, 2020), the educational differences between the children of migrant workers and urban children in cities (Chang \& Bu, 2020), all these demonstrated significant gap to reaching the accurate education equity. Especially after the outbreak of the COVID-19 pandemic, it has exacerbated the education losses of disadvantaged groups. The most marginalized groups, namely girls, people with disabilities, people in conflict areas, remote rural areas, and the poorest people, have become the groups most severely affected by school suspensions (Cheng et al., 2020; UNESCO, 2020).

The concept of educational equity contains two levels of content: the fairness of educational opportunities and the fairness of academic quality. At present, countries worldwide are committed to improving the fairness of educational opportunities and quality of education through inclusive education. As one of the countries that implement inclusive education most thoroughly globally, Italy attaches great importance to the formulation and implementation of inclusive education policies (Ianes, Demo, \& Dell'Anna, 2020; Morganti \& Cottini, 2016). After more than 40 years of development, more than $99.9 \%$ of students with disability are currently receiving education in regular schools and have gradually formed a more advanced inclusive education concept, sound laws and regulations (Gabel \& Danforth, 2008). Nevertheless, Italian researchers and policymakers have been working to improve professional support for teachers and the evaluation of the Italian full inclusion model. This has a demonstrative significance for the establishment of a global inclusive education system.

In China, the government solves uneven development of education quality between urban and rural areas and between regions through poverty alleviation through education to promote the equitable development of education. Promoted by China's poverty alleviation policies, a diversified poverty alleviation entity combining the state, society, schools, and individuals has emerged. Each entity adopts different forms of education to help poverty (Zhang, 2020; Zhu, 2020). These educational poverty alleviation projects have effectively improved the academic level and human capital of educationally impoverished areas, both in form and in substance, and promoted educational equity.

The three articles published in this issue of the journal separately studied the methods of Italy and China in the process of advancing educational 
equity. Gaggioli \& Sannipoli (2021) conducted a questionnaire survey on the attitudes of 544 Italian curriculum teachers and curriculum support teachers (counting 307 mainstream and 237 special-education teachers) on students with intellectual disabilities to better understand how these attitudes affected education. This article provided evidence and direction for the effective implementation of inclusive education from the perspective of evidence-based research. The Italian inclusive education system reflected in this research undoubtedly provides an Italian model for the establishment of education equity worldwide.

Wu and Qin (2021) and Hai (2021) were concerned about China's poverty alleviation by education. They elaborated on how China's poverty alleviation by education action can solve the inequity between educational opportunities, educational resources, and educational outcomes in poor and developed areas. From the perspectives of regional and individual poverty alleviation by education, they summarized China's regional and individual typical cases by means of educational narrative. In their studies, we can see that China promotes education equity through poverty alleviation by education, whether it is regional or individual assistance. Therefore, continuously condensing experience on the road of realizing social development has formed "Chinese stories."

At the same time, these studies also provide a new perspective for our understanding of education equity. Whether it is the deep implementation of inclusive education in Italy or the universally promoted preference alleviation by education in China, both strive to achieve fairness in the education process, that is, to treat every student equally, on the premise of attaining fair educational opportunities first. This also reflects the education equity theory of Coleman (1968) and Husén (1975), that is, by providing equal educational resources and educational opportunities, the equality of educational results can be achieved.

Even today's continuous development of society, education equity is also a theme that countries are constantly pursuing. Just as the education at a Glance 2017 released by the Organization for Economic Cooperation and Development in 2017 pointed out that proper and high-quality education can promote individual self-realization and bring economic growth to the country. "Countries should ensure that education meets the needs of today's children and has an impact on their future ambitions." (OECD, 2017).

\section{References}

Chang, L.R.R., \& Bu, Q.Y. (2020). Review on the compulsory education status of migrant workers' children in Chinese cities. Science Insights 
Education Frontiers, 7(2):861-877. DOI:

https://doi.org/10.15354/sief.20.re022

Cheng, X., Pellegrini, M., Zhou, L., \& Cheung, A., (2020). Not only survival but stronger: The impact of alarming invader of SARS-CoV-2 on global education. Science Insights Education Frontiers, 7(2):835-860. DOI: https://doi.org/10.15354/sief.20.or061

Coleman, S.J. (1968). The Concept of Equality of Educational Opportunity. Harvard Educational Review, 38(1):7-22. DOI: https://doi.org/10.17763/haer.38.1.m3770776577415m2

Cottini, L., \& Morganti, A. (2016). Does the school inclusion really work?. Education Sciences \& Society, 1:13-32. DOI: https://doi.org/10.3280/ess1-2016oa3240

Gabel, S.L., \& Danforth, S. (2008). Disability and the international politics of education. Peter Lang Inc., International Academic Publishers; Illustrated edition, pp41-pp52, ISBN: 978-082-048-894-3.

Gaggioli, C., \& Sannipoli, M. (2021). Improving the training of support teachers in Italy: The results of a research on attitudes aimed at students with intellectual disabilities. Science Insights Education Frontiers, 8(2):1037-1057. DOI: https://doi.org/10.15354/sief.21.or021

Hai, Y. (2021). Poverty alleviation by education is a kind of awakening and discovery: In memory of the "Poverty Alleviation War" of a retired middle school principal in eastern China. Science Insights Education Frontiers, 8(2):1097-1107. https://doi.org/10.15354/sief.21.rp001

Husén, T. (1975). Social Influences on Educational Attainment. Research Perspectives on Educational Equality [Sweden].

Ianes, D., Demo, H., \& Dell'Anna, S. (2020). Inclusive education in Italy: Historical steps, positive developments, and challenges. Prospects, 49:249-263. DOI: https://doi.org/10.1007/s11125-020-09509-7

International Bureau of Education, UNESCO. (2009). Defining an inclusive education agenda: reflections around the 48th session of the International Conference on Education. Geneva, Switzerland, 2009. November $25-28$.

http://www.ibe.unesco.org/sites/default/files/resources/defining_inclus ive education agenda 2009.pdf

OECD (2017), Education at a Glance 2017: OECD Indicators, OECD Publishing. DOI: https://doi.org/10.1787/eag-2017-en

UNESCO. (2020) Education: From Response to Recovery (2020-05-25)

[2021-4-7] https://zh.unesco.org/themes/educationemergencies/coronavirus-school-closures 
United Nations Department of Economic and Social Affairs. (2020). World Social Report 2020: Inequality in a radically changing world. New York City: United Nation.

World Bank. (2018). World Bank Report: Preventing girls from receiving education is costly. China Women's Daily, 07-18 (B3 edition).

Wu, J., \& Qin, B. (2021). Regional cooperation action of poverty alleviation by education in China: Documentary of pairing assistance action in Changxing County, Zhejiang Province. Science Insights Education Frontiers, 8(2):1081-1095. DOI:

https://doi.org/10.15354/sief.21.re014

Zhang, L. (2020). Overview of the poverty-alleviation by supporting education in China. Science Insights Education Frontiers, 6(2):631-651. DOI: https://doi.org/10.15354/sief.20.re010

Zhu, H.Q. (2020). Hope for girls' education in poverty-stricken areas: the school-running experience and process of Huaping Girls' High School in Yunnan, China. Science Insights Education Frontiers, 6(2):653-667. DOI: https://doi.org/10.15354/sief.20.or035

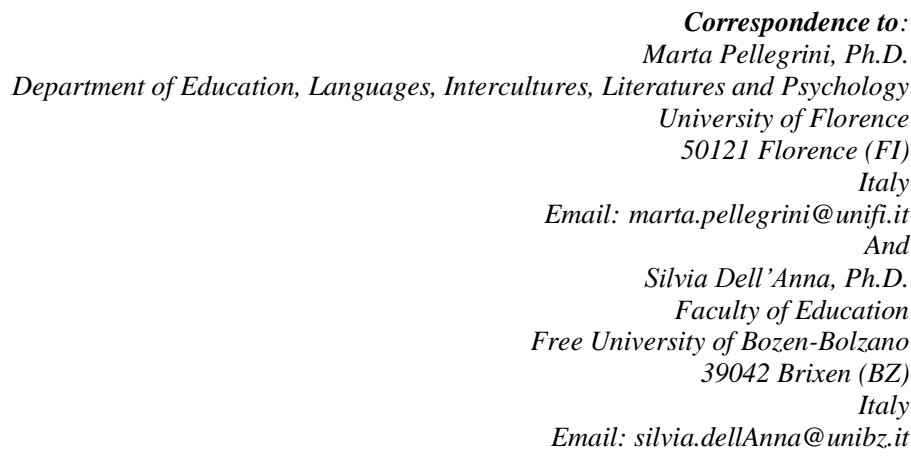

Conflict of Interests: None.

Doi: 10.15354/sief.21.ed007 